\title{
接着鼡・粘着剤の極限にせまる 現状と将来への夢
}

まず理想の接着剤の条件, 接着接合の特徵 (長短), '90 年代の 接着技術課題を提示した。次に最近の接着剤トレンドを機能性 接着剤というコンセプトでとらえ, 弾性, 反応性ホットメル 卜，油面および粘-接着剤を概説した。さらに接着剤と環境問 中島 常雄

Tsuneo Nakajima もとコニシ(株)

題をとり上げ，最後に将来への接着剤の夢を，究極の接着剤の

未来予測例と共に示した。

\section{1.はじめに}

理想の接着剂とは，お互いに必要条件が相反するた めに現実には存在しない.

H.F. Mark ${ }^{1)}$ によると,「理想の接着剤とは濡れ面 または油面でも容易に使用でき，すべての被着材に塗 布でき，欠膠部のない接合を与え，硬化中は低収縮 で, できるだけ広範囲の温度でも高強度を保持し, 脆 化点が低く，摇変性（チキソトロピック）で急速に塗 り広げても垂れがなく，室温で短時間にセット（固 化，硬化）するものである」という。また，モノマー 形接着剤の処方の一例として，アクリロニトリル 50 部，N-メチロールアクリルアミド 10 部，2-エチル ヘキシルアクリレート 50 部, エチレングリコールジ メタクリレート 5 部, ポリメチルメタクリレート, 低 分子量 10 部, 重合促進凨 (レドックス系, BPO-ジ メチルトルイジンなど） 0.5〜10 部をあげている2).

上述の理想的接着剂のすべての条件を満足する単一 接着剂は現在ない。

しかし，比較的理想に近い接着剤はシアノアクリレ 一ト系などがある。このシアノ系接着剤の短所である 強䩲性, 而熱性, 作業性, 万能接着性などの改良は現 在も継続して行われている3).

\section{2. 接着接合の特徵}

接着接合の特徵（長所・短所）を表 14）に示す。 将来の接着剤の設計目標は表 1 の短所を改良し，し かも各種接着剤固有の短所（ここでは省略）を解決 し，できるだけ長所が生かせるような接合部位の設

\footnotetext{
Approach to Ultimate Adhesives and Pressure Sensitive Adhesives-Present Status and Dreams to the Future
}

計，適した目的，用途にこの接着接合を利用する方向 になるであろう。

\section{3. 接着関連技術開発課題}

10 年前にファインケミカルビジョン研究委員会が まとめた' 90 年代接着関連技術課題を表 $2^{5)}$ に示す.

いずれにしても接着剈の研究開発の方向は,

(1)接着強さ，接着信頼性の向上…接着機能の向上

(2)硬化速度の向上‥生産性の向上, 省エネルギーな どのトータルコストの削減など

(3)無公害化…溶剤形から水系または 100\% 樹脂化

（無溶剤化）など

(4)特殊機能付加‥機能性接着剂など

の四つにまとめられる.

\section{4. 最近の接着剤のトレンド}

最近の接着剤のトレンドは，機能性接着剤というコ ンセプトでまとめられる。

\section{4-1. 機能と性能}

一般に材料の特性または物性を性能と機能の二つに 分類して区別している。

藤重 ${ }^{6)}$ によると，性能（performance）とは外部刺 激に対する抵抗力であり．接着強さ，耐水性，耐久性 などが属する，次に機能（function）とは物質に刺激

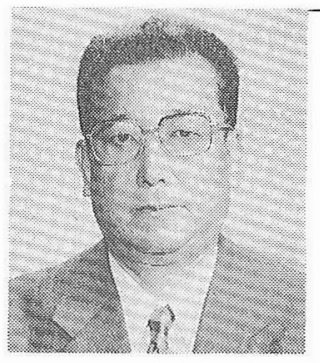
中島常雄 （自宅 213 川崎市高 津区下作延 319)

1955 年東農工大工学部工業化 学科卒. 同年コニシ入社, 浦和 研究所, ワックス研究所勤務, 1993 年退職。合成接着郕, シ ーラントの研究開発 (特にエポ キシ樹脂，ポリウレタン，酢ビ 樹脂など）に従事. <趣味>俳句，日躍大工 
表 1 接着剤接合の長所・短所

\begin{tabular}{|c|c|c|}
\hline 長 & 短 & 所 \\
\hline $\begin{aligned} & 1 . \text { 応力が均一に分布する. } \\
& 2 . \text { 被着材の変形を防ぎ, 構造を強化 } \\
& \text { する. } \\
& \text { 3. 疲れ強さを増大する. } \\
& 4 . \text { 異種材料の接合が可能. } \\
& 5 . \text { 接合に高温を必要としない. } \\
& 6 . \text { 振動を防止する. } \\
& 7 . \text { 重量を軽くする. } \\
& \text { 8. 表面を平滑にして,美観を与える. } \\
& \text { 9. 気密, 水密ができる. } \\
& \text { 10. 熱, 電気を絶縁する. }\end{aligned}$ & 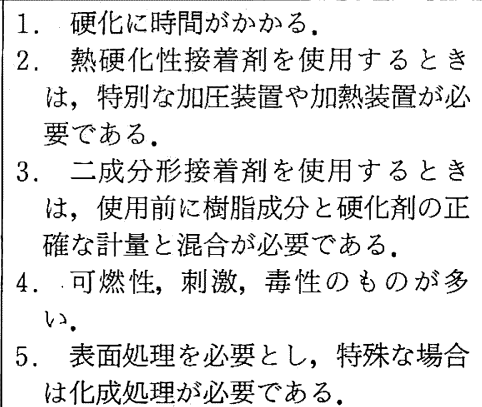 & 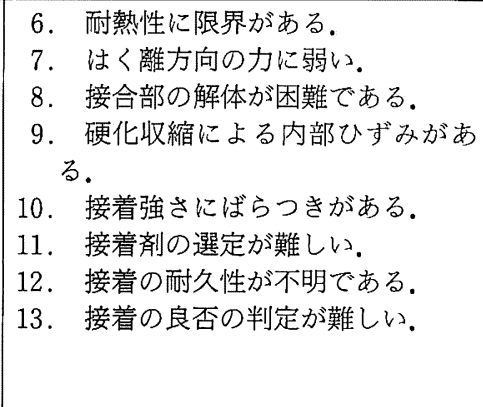 \\
\hline
\end{tabular}

などが入力されると，その質と量あるいはこのいずれ かを変化させて出力する能力と定義しており, 制振 性, 伝熱性, 吸油性, 導電性, 水中硬化性, 嫌気性な どが属する。

日本では，これらの機能と性能が結合されて機能性 と称しており, 欧米では高性能 (high performance) と総称しているのが慣例である.

機能性接着剤の分類は，古くは黄堂 ${ }^{7}$ による 26 分 類が有名であるが，最近のものでは柳沢8)によるもの がある。

これらの機能性接着剤の中で，ここでは最近注目を 浴びている弾性接着剤, 反応性ホットメルト接着剤, 油面接着剤と粘接着剤につきレビューしてみよう。

表 21990 年代接着関連技術開発課題

- 高性能高耐久性接着剤

・耐熱性接着剂

- 超低温用接着剂

A機能性接着剂（導電性接着剤等）

・ファインセラミックス用接着剂

・革新材料用接着剤

- 異種材料用接着剤

- 生体・医療用接着剂

（骨用，皮盧用，歯科用）

・接着剂のロボットおよび自動機適用技術

○信頼性評価技術の確立

耐久性測定技術（促進試験）

非破壊検査技術

- 低公害安全型化

（水系化または $100 \%$ 樹脂化）

- 接着表面処理技館

注：○……共通基盤技術, ...高機能

\section{4-2. 弾性接着㶡}

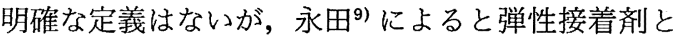
は，ゴムの硬さを有し，100〜200\% の伸びを有する， いわば反応形シーリング材の中で高弾性率（ハイモジ ュラス) タイプのものであるという.

成分的には(1)シリコーン系，(2)変成シリコーン系， (3)ポリサルファイド系, (4)ポリウレタン系, (5)エポキ シ系，6変性ポリマー系がある。

種類：1 成分形と 2 成分形の 2 つに大別される.

(長所) (1)外部応力を吸収する, (2)熱膨張係数差の大 きい異種材料の接着で生成する熱応力を緩和する，(3) 接着界面に応力が集中しにくい, (4)表面強度の弱い材 料（石こうボード, 珪カル板, ALC など）が接着で きる，(5)高いはく離強さが得られる。

(短所) (1)低い機械的強度，(2)而溶剂性が劣る。

「強い接着よりも，はがれない接着」というのが弾 性接着剤のコンセプトであるともいわれている.

\section{4-3. 反応性ホットメルト接着剂}

従来のホットメルト接着剂の短所である耐熱性 (本 質的には熱可塑性）を改良したものが，この夕イプで ある。

反応性ホットメルトの耐熱性向上手法としては，加 熱および湿気による架橋反応（分子間に網状結合を作 る反応）の 2 つが提案されている。この中で湿気によ る架橋が最も多く検討され，また上市されている。 (種類) 湿気による架橋形ホットメルト接着剤 (1)アルコキシリル基を利用するもの

アルコキシリル基をプリポリマーまたはオリゴマー に導入し，空気中の湿気で架橋させる。この手法は従 来のシリコーン系シーラントなどの分野ですでに実用 化されているものである。

(2)イソシアネート基を利用するもの

イソシアネート基 (-NCO) と空気中の湿気との反 応を利用した NCO 基を含有するウレタンプリポリマ 
一は，すでに一成分形ウレタン系シーラント，塗料の 分野で利用されている。そこでこのウレタンプリポリ マーの中でも常温で固体で, 加熱時に低粘度液状にな るものは反応性ホットメルト接着剤として利用でき る.

\section{4-4. 油面接着凧}

従来, 被着材の表面処理は接着接合の 4 システム (1)表面処理, (2)接着剤, (3)固化, (4)保証試験) の 1 つとして必要条件の 1 項目であった。しかし, 特殊変 性した接着剤を使用すれば，制限条件はあるが，ある 程度までは油面でも接着できる。

油の付着した下地面に接着剤を塗布すると, 油が接 着剤の中に吸収拡散されて高い接着強さを保持できる ものが吸油性接着剤（oil absorbent adhesive）または 油面接着剤 (oil accommodating adhesive) である.

このタイプの実用化の歷史は, 金属の接着では自動 車の油付き鋼板をクロロプレンゴム (CR) 系マスチッ ク形接着剤で組立接着したものが最初である. 以後こ れを順次改良してポリ塩化ビニル (PVC) 系プラスチ ゾルが，さらにエポキシ変性 PVC ゾルが，現在では ホットメルト形のエチレン・エチルアクリレート (EEA) 系やエポキシ系の油面接着剤が登場している. 従来, ニトリルゴム (NBR) 系や PVC 用に推奨さ れている他のゴム系接着剤や溶剤形接着剤が部分的に 油を吸収し，その結果被着材表面の油層を除去するか ら接着できるといわれてきた。

最近では被着材が金属ばかりでなく, コンクリー ト,ゴム，プラスチックなどにもそれぞれの表面に油 や成形時の離型剤が付着したままの成形品でも接着で きる油面接着剤が上市されてきた。

したがって接着剤も加熱硬化形のほかに, 常温硬化 形としてエポキシ樹脂系, 第二世代アクリル（SGA） 系, シアノアクリレート系, 嫌気性アクリレート系, ポリウレタン系, ビニルエステル（不飽和ポリエステ ル）系などの油面接着剤が次々と市販されている。

油面接着剤に関するレビュー10) や, 過去 20 年間の この接着剤の特許, 報文の調査結果 ${ }^{11)}$ がある.

\section{5. 最近の粘着剤のトレンド}

粘着剤 (感圧型接着片) とは, 「乾燥（溶剤が揮散 した）状態では室温で永久的に粘着性があり，軽い指 圧で簡単に被着体に密着させることで強固に接着する 接着剂」である。

粘着剤は一般の接着剤と違い, 粘着剂単独では使用 できないので，ラベル・テープ・シートとしてプラス チック，金属䈃，紙，布などの各種支持体に塗布され た粘着加工品（製品）として利用される.
表 3 最近の粘着ラベル・シートの開発製品群

\begin{tabular}{|c|c|}
\hline 製品群 & 例 \\
\hline リサイクル/環境問題適用ラベル & $\begin{array}{l}\text { ・リサイクル粘着製品 } \\
\text { 古紙含有粘着紙 } \\
\text { リサイクル可能な粘着紙 } \\
\text { ・リサイクル容器用阽着ラベル } \\
\text { ・脱塩ビ系粘着ラベル }\end{array}$ \\
\hline 情報関連粘着製品 & $\begin{array}{l}\text { ・物流，工程管理ラベル } \\
\text { ・繰り返し再貼付可能なラベル } \\
\text { ・特殊粘着はがき }\end{array}$ \\
\hline エレクトロニクス関連粘着製品 & $\begin{array}{l}\text { ・センサー, スイッチ部品 } \\
\text { ヘの粘着応用製品 } \\
\text { ・ディスプレイ関連粘着製品 } \\
\text { ・保護フィルム } \\
\text { ・ IC 関連粘着フィルム }\end{array}$ \\
\hline 車輛 - 建材関連粘着装品 & $\begin{array}{l}\text { ・マーキングフィルム } \\
\text { ・塗装代替フィルム } \\
\text { ・内装用粘着フィルム }\end{array}$ \\
\hline 医薬・食品関連粘着製品 & $\begin{array}{l}\text { ・高接着性ラベル(貼変え防止用) } \\
\text { ・いたずら防止用ラベル } \\
\text { ・無毒性ラベル } \\
\text { ・鮮度保持ラベル }\end{array}$ \\
\hline その他 & $\begin{array}{l}\text { ·自動車の保管場所標章 } \\
\text { ・盗難防止用ラベル } \\
\text { • 乾電池用シュリンクラベル } \\
\text { • 香料ラベル } \\
\text { • 粘着切手 }\end{array}$ \\
\hline
\end{tabular}

粘着剂も(1)感圧接着性, (2)瞬間接着性, (3)粘接着 性, (4)使い勝手の良さの四点で機能性接着剂である. さらに接着剤と異なる粘着剤の特徵として, (1)一貫し てゴム状態, (1)再はく離, 再接着が可能, (3)柔軟な分 子鎖の界面において再編する, (4)粘着製品は二次元複 合材料として種々の機能を発揮するの四点がある.

粘着製品の機能は従来, (1)マスキング, (2)保持, (3) 強化, (4)シール, (5)保護, (6)接続, (7)識別の 7 つであ つたが, 最近は(8)放出 (経皮吸収剂), (9)制振, (10般 送・装着, (11)光変換の 4 機能が追加され, 11 機能にな った ${ }^{12)}$.

最近の粘着ラベル・シートの開発製品について片山 が製品群別にまとめたものを表 $3^{13)}$ に示す.

\section{5-1. 粘接着剤}

粘接着剤の明確な定義はない。しかし，一般に硬化 前は粘着剤として機能するが, 接着後に何らかの方法 でこれを架橋させることにより, 接着強さを大幅に向 上させて接着剤として機能するのが粘接着剤である.

福沢 ${ }^{14)}$ は粘接着郕を次の 10 種に分類している. (1)両面接着フォームテープ (3 M 社 VHB タイプ), 
(2)熱硬化形粘着剤，(3)光硬化形粘着剤，(4)吸湿硬化形 粘着剂, (5)加圧形粘着剂, (6)嫌気性形粘接着剂, (7)硬 化剂溶液形粘接着剂, (8)水活性形粘接着剂, (9)熱活性 形粘着剤, (10)八ネムン (分別塗布) 形粘着剤.

この 10 種の中で(4)の湿気室温硬化形粘接着剤が実 用化されている。これは被着体に接着後, 粘着剤が空 気中や被着体中の湿気を吸収して化学反応で硬化する もので，代表的な官能基として，イソシアネート基や アルコキシシラノール基がある.

問題点として保存性の改良と接着特性の向上があ る.これらの問題点が解決されれば，粘着と接着の長 所を生かした理想に近い接着剤なので, 粘接着剤はよ り広範な分野に用途展開されていくであろう。

\section{6. 接着剤・粘着剤の環境問題}

環境問題のインパクトから考えると, 今後の接着剤 は, よりクリーンで, より安全な接着剤の処方と最終 用途と，高性能を結びつけたものになるであろう.

これらのアプローチは有害物質を除去することから 始まって揮発性有機物をできるだけ最小にし, リサイ クルできるか, 産業廃棄物が処分でき, できれば生分 解性のものに設計すべきである。

接着剤の環境問題インパクトは, その発生から消滅 まで, 原料メーカーおよび原料供給者, 接着剤メーカ 一および接着剂ユーザーの活動のすべてを含む.この 点でこれら三者による共同研究開発体制が必要とな る.

ただし，分解性と接着耐久性とは互いに相反するの で, これらの両立は難問であり, 分解性接着剤の用途 もごく限られた範囲に限定されるであるう。

\section{7. 将来の接着剤}

万能接着剤は現存しないので, 将来の接着剤は使用 方法, 用途, 性能を価格を限定して, これらの制限条 件に適合し，接着剤の短所（表 1) をできるだけ解決 したものになるであろう。

アメリカの R. Weil ${ }^{15)}$ の単行本「Omni Future Almanac (1982)」の将来予測では「究極の接着剂 (ultimate glue)」を次のように予測している.

「表面動力学を駆使することにより，化学者は今世 紀の終りまでに新しい接着剤を作り出すであろう。こ の接着剤は今まで使われてきたすべてのファスナーに とってかわるものである. 航空機の機体, ロケット, 宇宙プラットフォーム, 鉄道のレールは高性能の接着 凨によって接合されるようになる。技術者達は, これ らの接着剤を使って非常に多数の材料からできた積層 物（laminates）を作り出すことができる. 21 世紀の
初めには釘，ネジ，リベットは博物館でしかお目にか かれなくなるかも知れない.」

この究極の接着剤の実現は, 接着剤単独では無理か も知れないが，接着工法で，例えば機械的接合（溶接 など）を併用すれば，現在でも自動車，航空機などで 溶接接着として既に実用化されていることからして, 全くの夢物語ではないであろう.

かつての医術が現在の医学という学問体系に確立さ れたように, 現在の接着技術が近い将来「接着学」と して体系化されることを期待したい.

この「接着学」が確立されるためには, 前提条件と してさらに接着理論を整理統合して一本化でき，また 接着剤の分子・材料設計が自由自在に可能となり, 耐 久性, 而候性, 信頼性などの裏付けとなるべき接着デ ータベースが確実に構築されなければならない.

そこで, 現在以上に産・学・官の三者が協力して共 同研究開発システムなどを作り,「接着学」の体系化 に注力すべき時期にきていると思う.

また，今後の接着剤・粘着剤用の新原材料の出現や， 接着工法を含めたハード・ソフトの技術革新ないしは 進歩に期待する。

接着剤の 21 世紀で究極の接着剤が出現することを 夢見て，夢が正夢にならんことを祈る。

\section{文献}

1) H.F. Mark : Symposium of Adhesion and Cohesion, Polytech. Inst. of Brooklyn, (1961)

2) H.F. Mark: Adhesion and Cohesion, Elsevier, (1962), p.214

3) J.T. O'connel et al.: Mater. Eng, 109 [3] 14 (1962)

4）若林一民: 接着, 32 [4] 163 (1988)

5）ファインケミカルビジョン研究会：ファインケミカル の現状と将来, 化学工業日報社, (1984）p.45

6）藤重昇永ほか：機能性高分子材料，オーム社，(1984） p.1

7）黄堂慶雲：工業材料, 35 [10] 35 (1985)

8）小野昌孝編（柳沢誠一の項）：新版：接着と接着剂, 日 本規格協会, (1989) p.73

9）永田宏二：MOL, 28 [4] 107 (1990)

10） J.A. Graham : Mach. Des., 49, [28] 183 (1977) ; 中島 常雄: 工業材料 37 [12］150（1989）; 大栗靖弘：工業 材料, 39 [9] 133 (1991); Hong S.G. et al.: Jr of Adhesion, 32 [2/3] 67 (1990)

11）中島常雄: 油面接着剂, 第 171 回月例講演会資料, 日本 接着学会関東支部, (1994)

12）堀 豊：接着便覧，第 18 版，高分子刊行会，(1993） p.79

13）片山 明: 日接学会誌, 28, [4] 143 (1992)

14）福沢敬司：接着の技術 9, [2] 2 (1990)

15) R. Weil : The Omni Future Almanac, Omni Publ. Internat., p.21 (1982) 